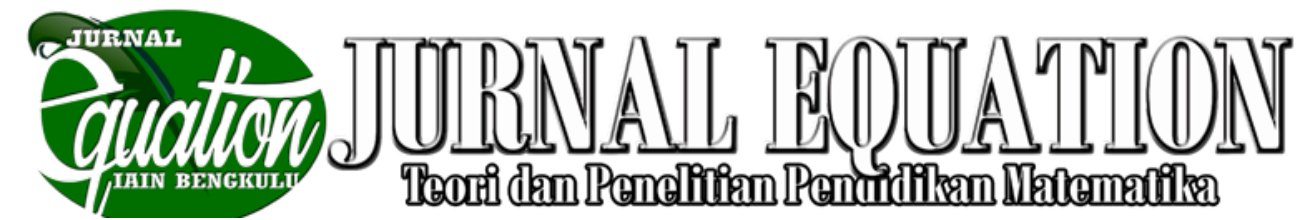

Volume 1 Nomor 2, September 2018, ISSN 2599-3291 (Cetak), ISSN 2614-3933 (Online)

\title{
Penggunaan Permainan Nara (Nata Alam Raya) dalam Meningkatkan Kemampuan Penalaran Siswa pada Materi Operasi Bilangan
}

\author{
Wahyu Cahyadi 1), Gusti Suryadi 2), Apriliza Dotari3) \\ Fakultas Tarbiyah dan Tadris, IAIN Bengkulu \\ wahyuchy4@gmail.com
}

\begin{abstract}
ABSTRAK
Operasi hitung dalam matematika terdiri dari penjumlahan, pengurangan, pembagian dan perkalian. Dalam proses belajar matematika masih banyak siswa yang mengalami kesulitan dalam materi operasi hitung bilagan bulat. Permainan yang bisa diberikan kepada siswa dan memberikan dampak positif bagi siswa dari segi pelajaran maupun keasyikannya yaitu permainan NARA (Nata Alam Raya). Permainan NARA (Nata Alam Raya) adalah sebuah permainan yang diperuntukkan bagi siswa untuk melatih operasi bilangan, seperti bilangan 2 angka, penjumlahan, pengurangan, perkalian, pembagian, pecahan, dan campuran. NARA (Nata Alam Raya) marupakan kartu yang terdiri dari angka $0,1,2,3,4,5,6,7,8$, dan 9 sebanyak enam set (total ada kartu 60 kartu), aturan permainan, dan papan panduan operasi. Kartu NARA (Nata Alam Raya) cocok dimainkan bagi kalangan pelajar SD, SMP, SMA, guru, hingga kalangan masyarakat umum yang sudah memiliki pengetahuan dasar mengenai operasi bilangan seperti penjumlahan, pengurangan, perkalian dan pembagian. Diharapkan permainan NARA (Nata Alam Raya) ini dilakukan dengan bimbingan orang yang sudah memahami konsep operasi hitung bilangan bulat agar siswa yang belum mahir dalam materi tersebut tidak mengalami kekeliruan terhadap materi operasi hitung bilangan bulat.
\end{abstract}

Kata Kunci : NARA, Operasi Bilangan, Penalaran

\section{PENDAHULUAN}

Pendidikan adalah sebuah usaha yang dilakukan secara sadar dan terencana untuk mewujudkan suasana belajar dan proses pembelajaran agar peserta didik sacara aktif mengembangkan potensi dirinya untuk memiliki kekuatan spiritual keagamaan, membangun kepribadian, pengendalian diri, kecerdasan, akhlak mulia, serta keterampilan yang diperlukan dirinya, masyarakat, bangsa dan negara. Salah satu upaya yang dilakukan peserta didik untuk mendapatkan pendidikan adalah belajar.

Belajar merupakan kegiatan yang wajib dilakukan oleh siswa sekolah maupun masyarakat lainnya. Matematika merupakan salah satu unsur dalam pendidikan. Pelajaran matematika harus diberikan kepada semua peserta didik, mulai dari sekolah dasar untuk membekali mereka dengan kemampuan berpikir logis (penalaran), analistis, sistematis, kritis, kreatif dan kooperatif. Salah satu tujuan pembelajaran matematika di sekolah adalah untuk melatih pola pikir dan penalaran dalam mengambil kesimpulan, mengembangkan kemampuan untuk memecahkan masalah, dan mengembangkan kemampuan untuk memberikan informasi atau mengkomunikasikan gagasan melalui lisan, 


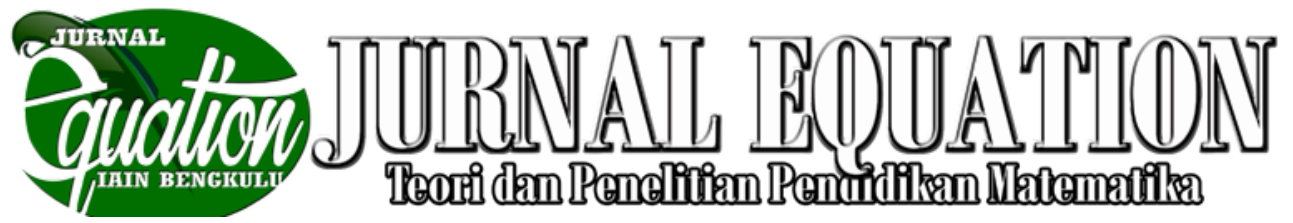

Volume 1 Nomor 2, September 2018, ISSN 2599-3291 (Cetak), ISSN 2614-3933 (Online)

tertulis, gambar, grafik, peta, diagram dan lain-lain. Matematika juga merupakan salah satu sarana untuk menumbuhkan keterampilan matematika siswa, logis, kreatif, kritis, teliti, sistematika, pemecahan masalah, komunikasi, keterampilan, dan representasi komunikasi.

Dalam kegiatan belajar matematika siswa akan aktif berhitung. Berhitung merupakan ilmu pengetahuan tentang bilangan, maka di dalam berhitung dapat ditemukan berbagai jenis bilangan dan segala aturan yang mengatur hubungan di antara bilangan-bilangan tersebut.

Berhitung merupakan suatu hal yang wajib dipahami oleh siswa. Hal ini disebabkan oleh semua aktivitas manusia akan selalu berkaitan dengan berhitung. Begitu pula hubungannya dengan matematika. Semua penyelesaian masalah dalam matematika akan selalu menggunakan hitungan.

Operasi hitung dalam matematika terdiri dari operasi perkalian, operasi pembagian, operasi penjumlahan dan operasi pengurangan.

Kurangnya penguasaan siswa terhadap materi operasi hitung bilangan dapat kita atasi dengan mencari suatu cara ataupun metode baru yang membuat siswa menjadi lebih tertarik dan mudah untuk memahami materi operasi perkalian, operasi pembagian, operasi penjumlahan, operasi pengurangan. Salah satu cara yang bisa kita lakukan contohnya yaitu mengajak siswa belajar sambil bermain permainan.

Permainan yang bisa diberikan kepada siswa dan memberikan dampak positif bagi siswa dari segi pelajaran maupun keasikannya yaitu bermainan NARA (Nata Alam Raya). Permainan NARA (Nata Alam Raya) adalah sebuah kartu permainan yang diperuntukan bagi siswa untuk melatih operasi, seperti perkalian, pembagian, penjumlahan dan pengurangan. Melalui permainan kartu ini siswa dapat meningkatkan pemahaman mereka terhadap materi operasi bilangan.

Berdasarkan latar belakang tersebut, maka penulis tertarik untuk menulis karya ilmiah yang berjudul "penggunaan permainan NARA (Nata Alam Raya) dalam meningkatkan kemampuan penalaran siswa pada materi operasi bilangan.

Tujuan dari penulisan karya ilmiah ini yaitu untuk mengetahui cara meningkatkan kemampuan penalaran siswa pada materi operasi bilangan dengan bermain kartu NARA (Nata Alam Raya).

\section{Permainan NARA}

Permainan NARA (NATA ALAM RAYA) adalah permainan yang diciptakan oleh Presiden Direktur Klinik Pendidikan MIPA 


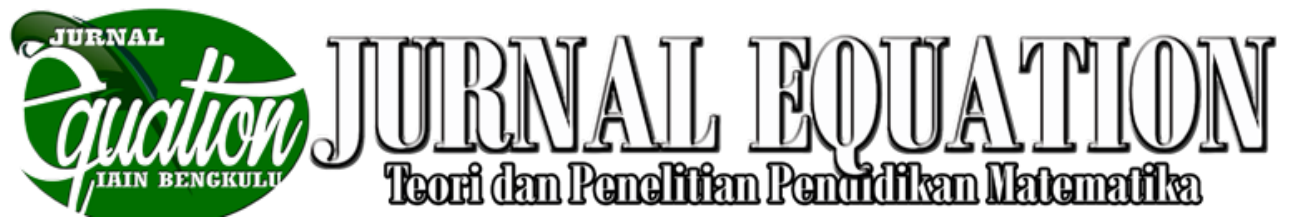

Volume 1 Nomor 2, September 2018, ISSN 2599-3291 (Cetak), ISSN 2614-3933 (Online)

(KPM), Ir. R Ridwan Hasan Saputra, M.Si. Ketika beliau mengikuti pesantren selama 3 bulan di Bayt Tamyiz, Indramyu, Jawa Barat di awal tahun 2016. Disela-sela kegiatan beliau menyempatkan mengajar matematika santri-santri disana yang rata-rata sudah lulus SMA. Beliau menemukan banyak santri-santri mengalami kesulitan berhitung. Lalu beliau mencoba mengajar berhitung dengan menggunakan metode kotak-kotak, dan alhasil para santri senior tersebut lebih terbantu memahami materi yang beliau sampaikan.

Saat itu beliau langsung terinspirasi untuk membuat permainan matematika agar siswa menjadi tertarik dengan matematika dan mereka menjadi mahir berhitung melalui permainan matematika menggunakan metode kotak-kotak. Akhirnya jadilah permainan NARA. Nama permainan ini berasal dari nama ketiga anak beliau, yakni Nata ( $R$. Jagadnata Ridwan Saputra), Alam (R. Surawisesa Ridwan Saputra), dan Raya (R. Rahayuningati Ridwan Saputra). Hal tersebut sebagai wujud penghargaan bagi mereka karena sering ditingggal pergi orang tuanya selama 3 bulan di pesantren.

Permainan NARA (Nata Alam Raya) adalah sebuah permainan yang diperuntukkan bagi siswa untuk melatih operasi bilangan, seperti bilangan 2 angka, penjumlahan, pengurangan, perkalian, pembagian, pecahan, dan campuran.

\section{Penalaran}

Penalaran adalah suatu proses berpikir dengan menggunakan landasan logika untuk menarik kesimpulan berdasarkan fakta (premis) yang telah dianggap benar. Menurut Zulfa (2014:2) menyatakan penalaran merupakan suatu kegiatan, suatu proses atau suatu aktivitas berpikir untuk menarik kesimpulan atau membuat pernyataan baru berdasarkan pada pernyataan yang kebenarannya telah dibuktikan sebelumnya dan menarik kesimpulan dengan cara mengaitkan fakta-fakta yang ada.

Menurut Subanidro

(2012:811) menyatakan bahwa "kemampuan penalaran matematik adalah kemampuan untuk menghubungkan antara ide-ide atau objekobjek matematika, membuat, menyelidiki, mengevaluasi dengan matematik, dan mengembangkan argumen-argumen dan bukti-bukti matematika untuk meyakinkan diri sendiri dan orang lain bahwa dugaan yang dikemukakan adalah benar."

Sumartini (2015:4) menyatakan bahwa penalaran matematis menyatakan suatu kebiasaan otak seperti halnya kebiasaan yang lain yang harus dikembangkan secara konsisten dengan menggunakan berbagai macam konteks. 


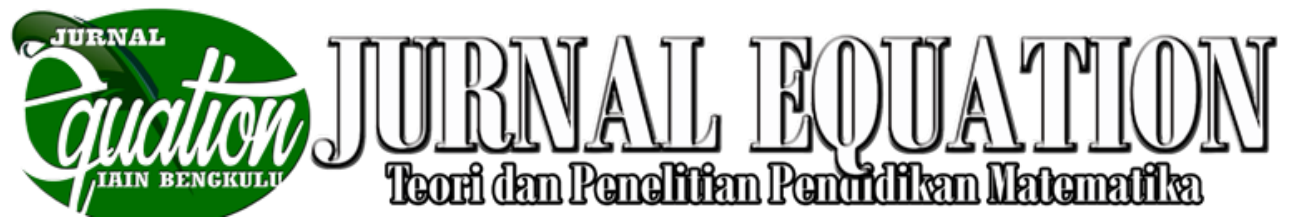

Volume 1 Nomor 2, September 2018, ISSN 2599-3291 (Cetak), ISSN 2614-3933 (Online)

Brodie (2009) menyatakan bahwa "Mathematical reasoning is reasoning about and with the object of mathematics". Yang artinya bahwa penalaran matematika adalah kemampuan seorang (anak) melakukan inferensi-inferensi logis berdasarkan fakta/pernyataan matematika yang ada.

Dari beberapa pendapat beberapa ahli di atas dapat disimpulkan bahwa kemampuan penalaran dalam matematika adalah suatu kemampuan menggunakan aturan-aturan, sifat-sifat atau logika matematika untuk mendapatkan suatu kesimpulan yang benar.

Penalaran dibagi menjadi dua yakni, penalaran deduktif dan induktif.

1. Penalaran Deduktif

Penalaran deduktif merupakan penarikan kesimpulan dari hal yang umum menuju hal yang khusus berdasarkan fakta-fakta yang ada. Menurut Soemarmo dan Hendriana (2014:38) penalaran deduktif adalah penarikan kesimpulan berdasarkan aturan yang disepakati. Nilai kebenaran dalam penalaran deduktif bersifat mutlak benar atau salah dan tidak keduaduanya bersama-sama. Beberapa hal yang tergolong pada penalaran deduktif adalah sebagai berikut: a) Melaksanakan perhitungan berdasarkan aturan atau rumus tertentu.

b) Menarik kesimpulan logis berdasarkan aturan inferensi berdasarkan proporsi yang sesuai, berdasarkan peluang, korelasi antara dua variable.

c) Menyusun pembuktian langsung, pembuktian tak langsung dan pembuktian dengan induksi matematika.

d) Menyusun analisis dan sintesis beberapa kasus.

Penalaran deduktif menjamin kesimpulan yang benar jika premis dari argumennya benar dan argumennya valid (logis).

2. Penalaran Induktif

Penalaran induktif merupakan suatu proses berfikir dengan mengambil suatu kesimpulan yang bersifat umum atau membuat suatu pernyataan baru dari kasus-kasus yang khusus. Soemarmo dan Herdriana (2014:33) mengemukakan beberapa kegiatan yang tergolong penalaran induktif yaitu sebagai berikut.

a) Transduktif yaitu menarik kesimpulan dari suatu kasus atau sifat khusus yang satu diterapkan pada kasus yang khusus lainnya. 
Volume 1 Nomor 2, September 2018, ISSN 2599-3291 (Cetak), ISSN 2614-3933 (Online)

Analogi yaitu penarikan kesimpulan berdasarkan keserupaan data atau proses.

b) Generalisasi yaitu penarikan kesimpulan umum berdasarkan sejumlah data yang teramati.

c) Memperkirakan jawaban, solusi atau kecenderungan, interpolasi, dan ekstrapolasi.

d) Member penjelasan terhadap model, fakta, sifat, hubungan, atau pola yang ada.

e) Menggunakan pola hubungan untuk menganalisis situasi dan menyusun konjektur.

Penalaran memiliki suatu standar tertentu. Standar penalaran dalam National Council of Teacher of Mathematics (2000) meliputi:

1) Mengenal penalaran sebagai aspek mendasar matematika.

2) Membuat dan menyelidiki dugaan matematika.

3) Mengembangkan dan mengevaluasi argumen matematika.

4) Memilih dan menggunakan berbagai tipe penalaran,

Menurut Permendikbud Nomor 58 tahun 2014 tentang aktifitas yang dinilai di dalam penalaran matematika siswa meliputi:

1) Mengajukan dugaan (conjecture).
2) Menarik kesimpulan dari suatu pernyataan.

3) Memberikan alternatif bagi suatu argument.

4) Menemukan pola pada suatu gejala matematis.

Berdasarkan beberapa uraian di atas, maka pada penelitian ini indikator yang ingin diukur oleh peneliti antara lain:

1) Kemampuan mengajukan dugaan adalah kemampuan siswa dalam memperkirakan suatu kebenaran pada permasalahan atau soal.

2) Kemampuan menemukan pola atau sifat dari gejala matematis untuk membuat solusi adalah kemampuan memberikan solusi berdasarkan apa yang sudah diketahui untuk menyelesaikan permasalahan atau soal.

3) Kemampuan menyusun bukti dan memberikan alasan terhadap kebenaran solusi adalah kemampuan siswa dalam memberikan bukti atau alasan terhadap solusi dari permasalahan atau soal.

4) Kemampuan menarik kesimpulan dari pernyataan adalah kemampuan siswa dalam menarik suatu kesimpulan dari pernyataan sebagai penyelesaian 


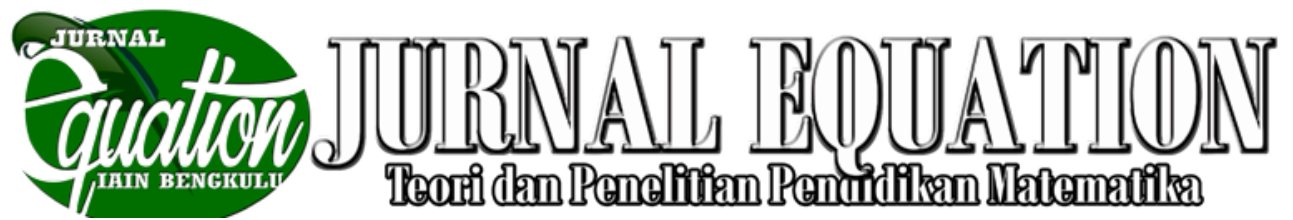

Volume 1 Nomor 2, September 2018, ISSN 2599-3291 (Cetak), ISSN 2614-3933 (Online)

suatu solusi dari permasalahan atau soal.

Penalaran dalam matematika memiliki peranan yang sangat penting dalam proses berpikir seseorang. Penalaran juga merupakan pondasi dalam pembelajaran matematika. Bila kemampuan bernalar siswa tidak dikembangkan, maka bagi siswa matematika hanya akan menjadi materi yang mengikuti serangkaian prosedur dan meniru contoh-contoh tanpa mengetahui maknanya. Materi matematika dan penalaran matematika merupakan dua hal yang tidak dapat dipisahkan yaitu materi matematika dipahami melalui penalaran dan penalaran dipahami dan dilatih melalui belajar materi matematika. Kemampuan penalaran matematika membantu siswa dalam menyimpulkan dan membuktikan suatu pernyataan, mambangun gagasan baru, sampai pada menyelesaikan masalah-masalah dalam matematika. Oleh karena itu, kemampuan penalaran matematis harus selalu dibiasakan dan dikembangkan dalam setiap pembelajaran matematika. Pembiasaan tersebut harus dimulai dari kekonsistenan guru dalam mengajar terutama dalam pemberian soal-soal yang non rutin.

\section{Operasi Bilangan}

Matematika adalah mata pelajaran yang sangat erat kaitannya dengan operasi hitung. Hampir dalam setiap materi matematika selalu menggunakan operasi hitung. Hal ini berarti bahwa keterampilan operasi hitung menjadi bagian yang sangat penting dalam matematika dan mutlak diperlukan agar siswa dapat belajar matematika dengan baik. Jika keterampilan ini belum dikuasai dengan baik, maka pembelajaran matematika akan terhambat.

Ada beberapa operasi hitung yang dapat dikenakan pada bilangan Operasi-operasi tersebut adalah : (1) penjumlahan; (2) pengurangan; (3) perkalian; (4) pembagian.

1) Penjumlahan

Operasi penjumlahan pada dasarnya merupakan suatu aturan yang mengaitkan setiap pasang bilangan dengan bilangan yang lain. Operasi penjumplahan ini mempunyai beberapa sifat yaitu:

a) Sifat asosiatif (pengelompokan)

$$
\begin{aligned}
& (a+b)+c=a+(b+c) \\
& \text { Contoh: }(5+3)+4=5+(3+4)=12
\end{aligned}
$$

b) Sifat komutatif (pertukaran)

$$
a+b=b+a
$$

Contoh: $7+2=2+7=9$ 
Volume 1 Nomor 2, September 2018, ISSN 2599-3291 (Cetak), ISSN 2614-3933 (Online)

c) Unsur identitas terhadap penjumlahan

Bilangan nol (0) disebut unsur identitas atau netral terhadap penjumlahan.

$a+0=0+a$

Contoh: $6+0=0+6$

2) Pengurangan

Operasi pengurangan merupakan kebalikan dari operasi penjumlahan, tetapi operasi pengurangan tidak memiliki sifat yang dimiliki operasi penjumlahan. Operasi pengurangan tidak memenuhi sifat pertukaran, sifat identitas, dan sifat pengelompokan.

a) Untuk sembarangan bilangan bulat berlaku

$a-b=a+(-b)$ dan $a-(-b)=a+b$

Contoh: 8- $5=8+(-5)=3$ dan 7 - (-

4) $=7+4=11$

b) Sifat komutatif dan asosiatif tidak berlaku

$a-b \neq b-a$ dan $(a-b)-c \neq a-(b-$

c)

Contoh: $8-2 \neq 2$ - $8 \Rightarrow 6 \neq-6$ dan $(9-4)-3 \neq 9-(4-3)=>2 \neq 8$

c) Pengurangan bilangan nol mempunyai sifat

$a-0=a$ dan $0-a=-a$

Contoh: $4-0=4$ dan $0-6=-6$

3) Perkalian

Operasi perkalian dapat didefinisikan sebagai penjumlahan berulang. Operasi perkalian ini mempunyai beberapa sifat yaitu:

a) Hasil perkalian dua bilangan bulat positif adalah bilangan bulat positif.

$a \times b=a b$

Contoh: $7 \times 6=6 \times 7=42$

Hasil perkalian bilangan bulat positif dengan negatif hasilnya adalah bilangan bulat negative.

$a x-b=-a b$

Contoh: $3 x-4=-12$

Hasil perkalian dua bilangan negatif adalah bilangan bulat positif.

$-a x-b=a b$

Contoh: $-4 x-5=20$

b) Sifat asosiatif

$(a \times b) \times c=a \times(b \times c)$

Contoh: $(2 \times 3) \times 4=2 \times(3 \times 4)=24$

c) Sifat komutatif

$a \times b=b \times a$

Contoh: $4 \times 5=5 \times 4=20$

d) Sifat distributif

$a \times(b+c)=(a \times b)+(a \times c)$

Contoh: $3 \times(2+6)=(3 \times 2)+(3 \times 6)$ $=24$

e) Unsur identitas untuk perkalian

Hasil perkalian bilangan bulat dengan nol hasilnya adalah bilangan nol.

$\mathrm{a} \times 0=0$

Contoh: $3 \times 0=0$ 
Volume 1 Nomor 2, September 2018, ISSN 2599-3291 (Cetak), ISSN 2614-3933 (Online)

Hasil perkalian bilangan bulat dengan 1 hasilnya adalah bilangan bulat itu sendiri

$\mathrm{a} \times 1=1 \times a=a$

Contoh: $2 \times 1=1 \times 2=2$

4) Pembagian

Operasi pembagian dapat didefinisikan sebagai pengurangan berulang Secara matematis ditulis sebagai $a: b=a-b-b-b-b \ldots=0$. Misal $24: 8=24-8-8-8=0$, berarti $24: 8=3$. Hasil ini ditunjukan oleh banyaknya angka 8 yang muncul sebagai bilangan pengurangannya. Operasi pembagian adalah kebalikan dari operasi perkalian. Jika sebuah bilangan a dibagikan bilangan $b$ menghasilkan bilangan $\mathrm{C}$ (dapat dilambangkan dengana: $b=c$ ), maka konsep perkalian yang terkait adalahc $\mathrm{x}$ $b=a$. Operasi pembagian memiliki sifatsifat sebagai berikut:

a) Hasil bagi dari dua bilangan bulat positif adlah bilangan positif.

$(+):(+)=(+)$

Contoh: $8: 2=4$

b) Hasil bagi dua bilangan bulat negatif adalah bilangan positif.

$(-):(-)=(+)$

Contoh: $-10:-5=2$ c) Hasil bagi dua bilanhan bulat yang berbeda adalah bilangan negative.

$(+):(-)=(-)$ dan $(-):(+)=(-)$

Contoh: $6:-2=-3$ dan $-12: 3=-4$

d) Hasil bagi bilangan bulat dengan 0 (nol) adalah tidak terdifinisi.

a : $0=>$ tidak terdefinisi $(-)$

$0: \mathrm{a}=>0(\mathrm{nol})$

e) Tidak berlaku sifat komutatif dan asosiatif.

$a: b \neq b: a$ dan $(a: b): c \neq a:(b: c)$

Contoh: $4: 2 \neq 2: 4 \Rightarrow 2 \neq 1 / 2$ dan $(8$ :

2) $: 4 \neq 8:(2: 4) \Rightarrow 1 \neq 16$

f) Bersifat tidak tertutup.

Jika dua bilangan bulat dibagi hasilnya belum tentu bilangan bulat juga

Contoh: $6: 2=3$ (bilangan bulat) dan $7: 2=3 \frac{1}{2} \quad$ (bukan bilangan bulat melainkan bilangan pecahan).

Operasi-operasi tersebut memiliki kaitan yang sangat erat sehingga pemahaman konsep dan keterampilan melakukan operasi yang satu akan mempengaruhi pemahaman konsep dan keterampilan operasi yang lain.

\section{METODOLOGI PENULISAN}

Penulisan karya tulis ilmiah yang berjudul "Penggunaan permaianan NARA (Nata Alam Raya) dalam meningkatkan kemampuan penalaran siswa pada materi operasi 


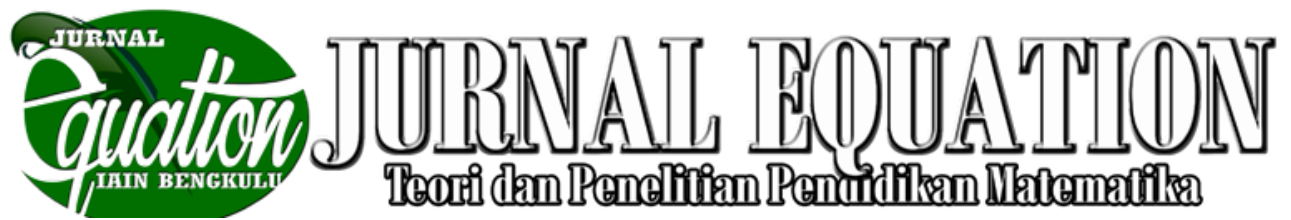

Volume 1 Nomor 2, September 2018, ISSN 2599-3291 (Cetak), ISSN 2614-3933 (Online)

bilangan."menggunakan metode deskriptif kualitatif.

Sumber data penelitian ini terdiri atas dua jenis, yakni person and paper. Person adalah data yang diperoleh dari hasil observasi atau wawancara orang yang menjadi subjek penelitian. Paper adalah sumber data yang diperoleh dari dokumen atau tulisan yang berupa karya ilmiah, artikel, jurnal, skripsi, tesis, maupun laporan-laporan.

Sasaran utama permainan NARA (Nata Alam Raya) dalam pembelajaran matematika adalah siswa sekolah dasar (SD). Hal ini dikarenakan siswa menerima materi operasi bilangan pertama kali saat dibangku sekolah dasar (SD).

\section{HASIL DAN PEMBAHASAN}

Kartu NARA (Nata Alam Raya) merupakan sebuah permainan kartu yang diperuntukkan bagi siswa untuk melatih operasi hitung, seperti penjumlahan, pengurangan, perkalian, dan pembagian. Selain itu, manfaat dari permainan ini juga memperkenalkan tentang bilangan terbesar, bilangan terkecil hingga pecahan sederhana.

Kartu NARA cocok dimainkan bagi kalangan pelajar SD, SMP, SMA, guru, hingga kalangan masyarakat umum yang sudah memiliki pengetahuan dasar mengenai operasi bilangan seperti penjumlahan, pengurangan, perkalian dan pembagian. Didalam permainan ini juga telah disediakan kartu dari angka 0-9 sebanyak enam set (total ada kartu 60 kartu), aturan permainan, dan papan panduan operasi.

Permainan NARA (Nata Alam Raya) memiliki beberapa aturan diantaranya yaitu:

\section{Panduan Operasi Bilangan}

\begin{tabular}{|c|l|l|l|}
\hline No & \multicolumn{1}{|c|}{ Operasi } & Terbesar & Terkecil \\
\hline 1. & Bilangan 2 angka & & \\
\hline 2. & Penjumlahan & & \\
\hline 3. & Pengurangan & & \\
\hline 4. & Perkalian & & \\
\hline 5. & Pembagian & & \\
\hline 6. & Pecahan & & \\
\hline 7. & Campuran & & \\
\hline
\end{tabular}

\section{Aturan Main dan Pemenang}

a) Aturan main

1) Pemain bisa terdiri dari $2-4$ orang.

2) Pemain melakukan suit/hompipah untuk menentukan siapa duluan yang bermain.

3) Kartu dikocok, kemudian dibagikan (seorang pemain mendapatkan 3 kartu).

4) Pemain yang mendapatkan giliran pertama berhak menentukan operasi hitung. (Contoh: Ketika pemain pertama memilih operasi hitung penjumlahan terbesar, maka 
Volume 1 Nomor 2, September 2018, ISSN 2599-3291 (Cetak), ISSN 2614-3933 (Online)

semua pemain memilih masing-masing 2 dari 3 kartu miliknnya untuk dijumlahkan, kemudian pemain dengan jumlah terbesar berhak mengambil semua kartu).

5) Operasi yang sudah dipakai dicontreng pada table dan tidak boleh digunakan lagi.

6) Pemain yang mengumpulkan kartu berhak menentukan operasi hitung selanjutnya.

7) Jika pada peletakan kartu terjadi. (1) Ada dua/lebih pemain yang memiliki hasil operasi yang sama dan kartunya sama maka perolehan kartu di bagi rata. (2) Ada dua/lebih pemain yang memilikki hasil operasi sama tapi kartu berbeda maka kartu di ambil oleh pemain yang memiliki angka yang lebih besar jika pemain pada operasi terbesar dan angka terkecil pada operasi terkecil.

Contoh:

Dalam operasi selisih terkecil, pemain dengan kartu 1 dan 1 , lebih berhak mengambil kartu dari pemain kartu 8 dan 8 .
Dalam operasi jumlah terbesar, pemain dengan kartu 9 dan 2, lebih berhak mengambil kartu dari pemain dengan kartu 6 dan 5 .

8) Jika kartu tinggal 3 terakhir maka lebih dilakukakan operasi campuran. (Contoh: hasil terkecil dari pada dua bilangan di tambah dengan bilangan ketiga).

9) Operasi pengurangan merupakan selisih antara dua bilangan. (Contoh: terdapat $\begin{array}{lllll}\text { bilangan } & 3 & \text { dan } & 7 & \text { jika }\end{array}$ dinyatakan pengurangan terkecil maka hasilnya adalah 4,karena 4 merupakan selisih dari 3 dan 7).

10) Operasi pecahan merupakan operasi yang pembilangnya lebih kecil daripada penyebut. (Contoh: terdapat bilangan 1 dan 2 jika dinyatakan operasi pecahan maka 1 merupakan pembilang dan 2 merupakan penyebut jadi hasilnya adalah $1 / 2)$.

11) Operasi pembagian merupakan operasi yang memiliki sifat kebalikan dari operasi 


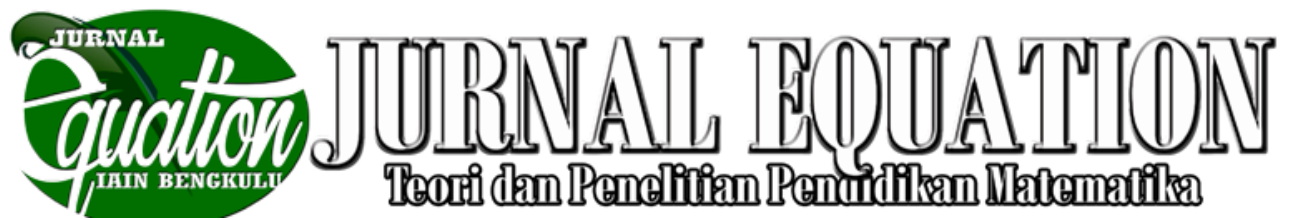

Volume 1 Nomor 2, September 2018, ISSN 2599-3291 (Cetak), ISSN 2614-3933 (Online)

pecahan. (Contoh: terdapat bilangan 1 dan 2 jika dinyatakan operasi pembagian maka 2 merupakan pembilang dan 1 merupakan penyebut jadi hasilnya adalah 2/1).

12) Operasi lain dalam permainan boleh di tambahkan sesuai dengan kesepakatan pemain.

b) Ketentuan pemenang

Pemain dikatakan menang jika mengumpulkan kartu paling bnyak di akhir pertandingan.

Dalam permainan NARA (Nata Alam Raya) membutuhkan strategi untuk menentukan operasi bilangan yang akan digunakan saat mendapatkan giliran dalam permainan tersebut. Strategi yang dibutuhkan adalah bagaimana memanfaatkan operasi yang masih ada dengan kartu yang siswa miliki sehingga daya penalaran siswa tersebut akan meningkat karena siswa tersebut mau tidak mau harus berfikir mengenai operasi bilangan apa yang sesuai untuk digunakan dalam permainan tersebut sehingga siswa tersebut bisa memenangkan permainan.

Contoh seorang siswa memiliki tiga buah kartu NARA (Nata Alam Raya) bernilaikan antara lain 0, 2 dan 3 sedangkan operasi bilangan yang tersisa bilangan 2 angka terbesar, perkalian terkecil, pengurangan terkecil, campuran terbesar dan campuran terkecil. Siswa tersebut memilih operasi bilangan campuran terkecil yakni campuran antara operasi penjumlahan dan operasi perkalian. Sehingga hasil hitung dari operasi tersebut adalah 0 karena susunan yang dia gunakan adalah $2+3 \times 0=0$. Alasan mengapa siswa tersebut lebih memilih operasi campuran terkecil daripada operasi perkalian terkecil karena jika siswa tersebut memilih operasi perkalian terkecil dia hanya mendapatkan dua kartu dari masing-masing pemain yang lain sedangkan jika dia memilih operasi campuran terkecil dengan susunan operasi penjumlahan dan operasi perkalian maka siswa tersebut akan mendapat tiga buah kartu dari masing-masing pemain yang lain.

Menurut Teguh Imam Agus Hidayat Litbang Klinik Pendidikan MIPA (KPM) kartu NARA (Nata Alam Raya) dapat meningkatkan kemampuan nalar anak melalui stratrgi yang dilakukan dalam rangka memenangkan permainan. Hal ini berkaitan dengan indikator penalaran yakni:

1. Siswa mampu mengajukan dugaan dari suatu permasalahan atau soal.

2. Siswa mampu menemukan pola atau sifat dari gejala matematis untuk membuat solusi.

3. Siswa mampu menyusun bukti dan memberikan alasan terhadap kebenaran solusi. 


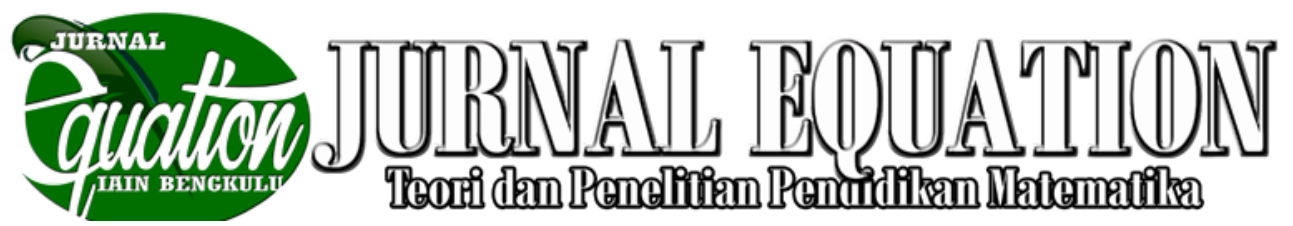

Volume 1 Nomor 2, September 2018, ISSN 2599-3291 (Cetak), ISSN 2614-3933 (Online)

4. Siswa mampu menarik kesimpulan dari pernyataan.

Keunggulan dari permainan NARA (Nata Alam Raya) dapat meningkatkan penalaran bagi siswa, melatih kemampuan operasi bilangan seperti penjumlahan pengurangan, pembagian, dan perkalian, mudah dimainkan, bisa dimainkan oleh semua kalangan, dan bisa dimainkan dimana saja.

Berikut adalah beberapa foto permainan NARA (Nata Alam Raya) dan foto saat bermain NARA (Nata Alam Raya).

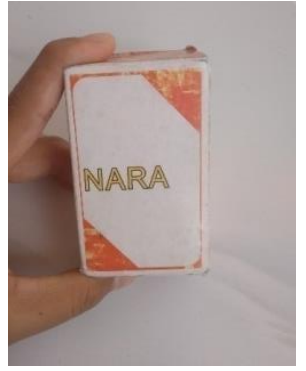

Kotak permainan NARA

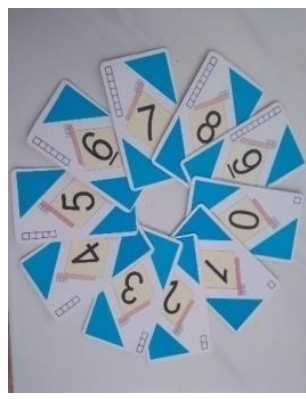

Kartu NARA

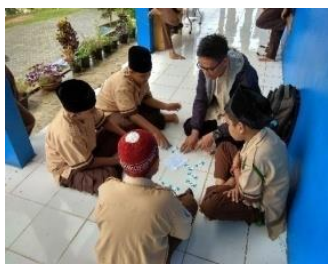

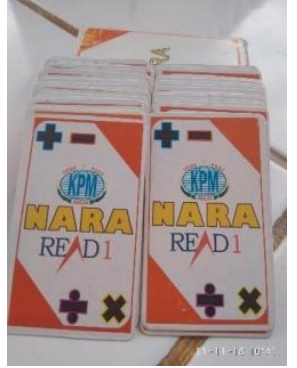

Kartu NARA

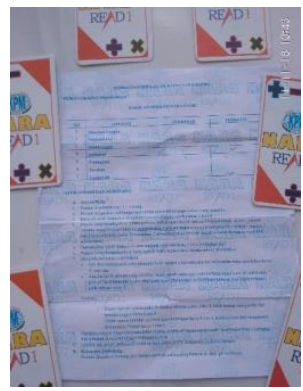

Aturan permainan NARA

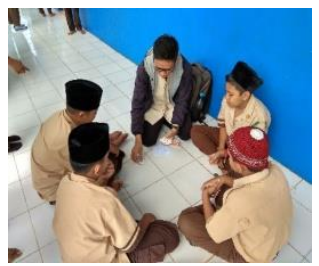

Foto saat bermain NARA dengan siswa SD IT Hidayatullah Kota Bengkulu

\section{PENUTUP}

\section{Kesimpulan}

Permainan NARA (Nata Alam Raya) bisa meningkatkan kemampuan penalaran siswa pada materi operasi bilangan karena dalam permainan NARA membutuhkan strategi untuk menentukan operasi bilangan yang akan digunakan saat mendapatkan giliran dalam permainan tersebut. Strategi yang dibutuhkan adalah bagaimana memanfaatkan operasi yang masih ada dengan kartu yang siswa miliki sehingga daya penalaran siswa tersebut akan meningkat karena siswa tersebut mau tidak mau harus berfikir mengenai operasi bilangan apa yang sesuai untuk digunakan dalam permainan tersebut sehingga siswa tersebut bisa menang.

Keunggulan dari permainan NARA (Nata Alam Raya) adalah dapat meningkatkan penalaran bagi siswa, melatih kemampuan operasi bilangan seperti penjumlahan pengurangan, pembagian, dan perkalian, mudah dimainkan, bisa dimainkan oleh semua kalangan, dan bisa dimainkan dimana saja.

\section{Saran}

Berdasarkan penjelasan di atas, maka kami merekomendasikan: 


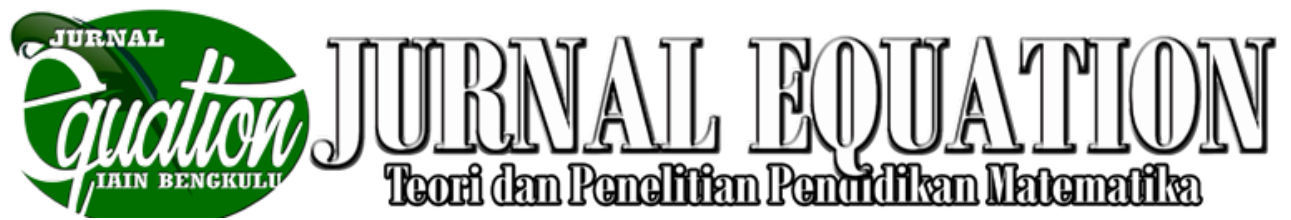

Volume 1 Nomor 2, September 2018, ISSN 2599-3291 (Cetak), ISSN 2614-3933 (Online)

1. Guru-guru khususnya guru Sekolah Dasar (SD) menggunakan permainan NARA (Nata Alam Raya) saat mengajarkan materi operasi bilangan karena permainan ini bisa membuat murid merasa senang dan tertarik untuk belajar operasi bilangan.

2. Diharapkan adanya penelitian lebih lanjut mengenai penggunaan permainan NARA (Nata Alam Raya) dalam meningkatkan kemampuan penalaran siswa pada materi operasi bilangan.

\section{DAFTAR PUSTAKA}

Amanda, Gita. 2018. "Serunya Belajar Matematika Lewat Permainan Kartu NARA".https://m.republika.co.id.Tan ggal diakses 25 September 2018.

Anonim. 2016. "NARA Games Dipopulerkan

Siswa KPM $d i$

Texas".www.bogorplus.com.

Tanggal diakses 25 September 2018.

Anonim.

2016.

"Bilangan".

http://id.m.wikipedia.org. Diakses tanggal 25 September 2018.

Anonim. 2018.

"Penalaran".

http://id.m.wikipedia.org. Diakses tanggal 25 September 2018.

Brodie, Karin. 2009. Teaching Mathematical Reasoning in Secondary School
Classroom. Springer Science \& Business Media.

Hidayat, Teguh Imam Agus. 2018. "Sejarah Lahirnya Ide Permainan NARA (Nata Alam

Raya)".http://kpmseikhlasnya.com.

Tanggal Diakses 1 November 2018. Natioanal Council of Teacher of Mathematics. 2000. Principle and Standars for School Mathmatics. Reston. VA: NCTM.

Permendikbud Nomor 58. 2014. Kurikulum 2013 SMP/MTS. Jakarta:

Depdikbud.

Subanidro. 2012:811. Pengembangan Perangkat Pembelajaran

Trigonometri Berorientasikan

Kemampuan Penalaran dan Komunikasi Matematika.

Sumartini, Tina Sri. 2015:4. Peningkatan Kemampuan Penalaran Matematis Siswa Melalui Pembelajarann Berbasis Masalah. Jurnal Pendidikan Matematika. Volume 5, Nomor 1. Hal: 1-10.

Soemarmo, Utari dan H Hendriana. 2014, "Penilaian Pembelajaran

Matematika". Bandung: Reflika Aditama.

Zulfa, Femilya Sri, dkk. 2014. Pengaruh

Penerapan Metode Penemuan Terbimbing Terhadap Kemampuan 
Volume 1 Nomor 2, September 2018, ISSN 2599-3291 (Cetak), ISSN 2614-3933 (Online)

Penalaran Matematis Siswa Kelas

XII IPA SMAN 1 Padang Panjang.
Jurnal Pendidikan Matematika UNP,

Part 1. Hal: 1-4. 